\title{
"O Aleijadinho": monstro herói
}

Luiz Armando Bagolin

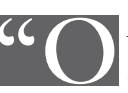

ALEIJADINHO", assim, entre aspas, expressa não mais do que um conjunto de representações que não necessariamente tem como origem um indivíduo chamado Antônio Francisco Lisboa, supostamente um artífice, mulato, forro, que viveu em Vila Rica e seus arredores, entre o final do século XVIII e o início do XIX. Como representação, entre outras representações, "o Aleijadinho" é um conceito que seguiu com vida própria à medida que foi se institucionalizando no Brasil, desde meados do século XIX, a par de interesses políticos nacionalistas, em primeiro lugar, mercadológicos, depois, não correspondendo nunca a uma unidade psicológica indecomponível.

Incorporando o termo tal como circula, sem aspas, o Aleijadinho, no livro intitulado Aleijadinbo e o aeroplano: o paraíso barroco e o herói nacional, de Guiomar de Grammont, é um misto de representações metodicamente por ela desconstruídas e analisadas a partir de uma estratégia arqueológica. Não interessa à sua pesquisa, contudo, descobrir em definitivo as mentiras e as verdades sobre o homem e a sua obra. Guiomar, ao contrário do que fizeram diversos historiadores, não está interessada em desvendar os mistérios sobre a vida e a morte do Aleijadinho, assim como não intenta demonstrar a verdade por detrás da farsa em torno de sua, suposta, existência. Tentar refutá-la, segundo a auto$\mathrm{ra}$, seria uma forma de fortalecer os discursos daqueles que a reiteraram, assim como os dos que ainda a alimentam.

Tampouco se propõe a analisar a obra escultórica atribuída àquele nome, como fizeram Bazin, Mário de Andrade e outros, com os olhos demasiadamente contaminados pelo mito. Aplica-se, pelo contrário, na investigação do personagem ou dos personagens nomeados Aleijadinho a partir da suposição de histórias e caracteres sobre o inventado. E embora saiba, com poucos, que o nome Aleijadinho tão somente classifica uma obra escultórica nas artes exercitadas em Minas Gerais do século XVIII, assim como um corpo de doutrinas artísticas por aqui operantes desde muito antes disso, Guiomar se interessa, particularmente, em seu livro, pelos critérios que mobilizaram a construção do Aleijadinho como representação autoral, genuinamente brasileira e genial, a partir de meados do século XIX, nos discursos literários, históricos e críticos.

Tal construção tem início, segundo a autora, com o discurso de Rodrigo José Ferreira Bretas, sócio do Instituto Histórico e Geográfico Brasileiro, publicado como biografia ou história de feitos memoráveis, em 1858, sob os auspícios de D. Pedro II. Lembra ao leitor que, à época, o Instituto proveu os meios para a invenção e o enaltecimento das tradições culturais brasileiras, sob o olhar atento do imperador, mediante o soerguimento de um panteão de heróis nacionais, ainda que inventados.

A invenção do Aleijadinho na persona do entalhador Antônio Francisco Lisboa, que provavelmente circulou pelas Minas Gerais do XVIII, coube a Bretas, segundo Guiomar, tendo investido a composição de sua biografia em gênero epidítico, que encomia obras e louva vi- 


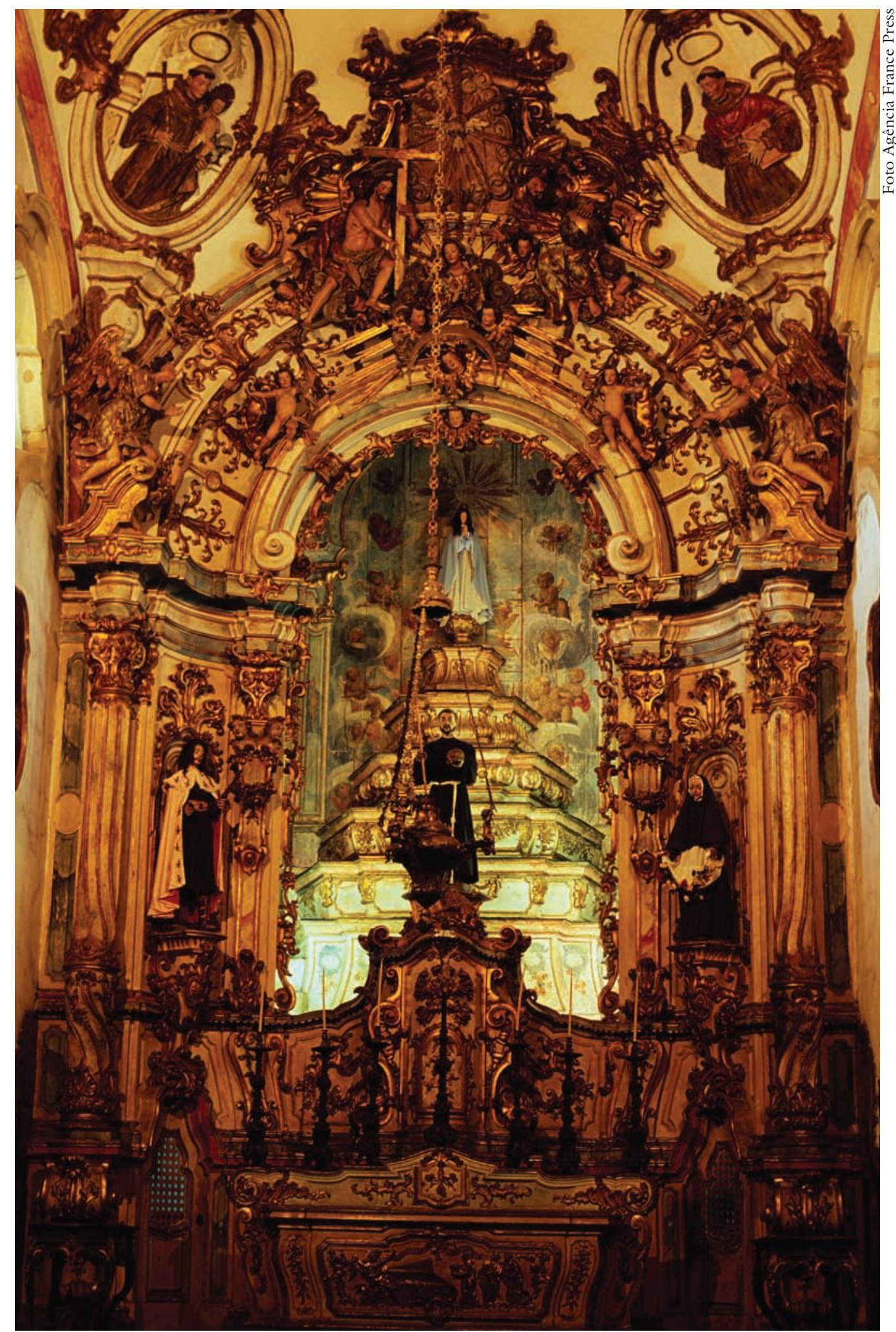

A Igreja de São Francisco de Assis, localizada em Ouro Preto(MG), é considerada uma das obras-primas do barroco brasileiro, além de ser uma das realizações atribuidas a Aleijadinho. 
das, emulando ao mesmo tempo a célebre novela de Victor Hugo, O corcunda de Notre-Dame, que era uma predileção nas leituras do imperador. Bretas, professor de retórica, foi hábil em montar uma biografia que move o leitor em direção à dor, sublime, da vida, deformada e finita, em confronto com a arte bela e infinda, operando por disjunções, quanto ao ethos, na composição do personagem Aleijadinho. Reúne com procedimentos retóricos do gênero referido, a baba romântica que circulava então, inventando (imitando ou compondo, não importa) o Livro de Registros de Fatos Notáveis da Cidade de Mariana do Vereador José Joaquim da Silva, que teria sido publicado em 1790, mas não passa de recurso para a instrução sobre o biografado, a conferir-lhe verossimilhança.

O discurso de Bretas, por sua vez, comove por oxímoro, como o belo-feio, ou o monstro que faz maravilhas. Retém-se também nessa oposição um dos critérios para as antigas coleções de mirabilia, as maravilhas, os maravilhosos, por exemplo, onde se compõem, de acordo com a ordo naturalis, os caprichos e grotescos, os fantásticos da natureza.

Do ponto de vista da composição, o monstro belo ou que faz coisas belas, apesar de ser feio e deformado, imita a inversão, que faz que céu e terra, paraíso e inferno se toquem na "sindérese", aristotélica, figurada, entre outros lugares, na relação "despropósito proporcional" e "propósito desproporcionado", no Il Canochialle, de Emanuelle Tesauro. Não necessitaria recorrer, embora o faça, para construir o ápice da composição daquele ethos, à genialidade, como conceito kantiano exposto na terceira crítica.

Monstruoso, genial e genuíno, nascido em terras brasileiras, e sem laços que,

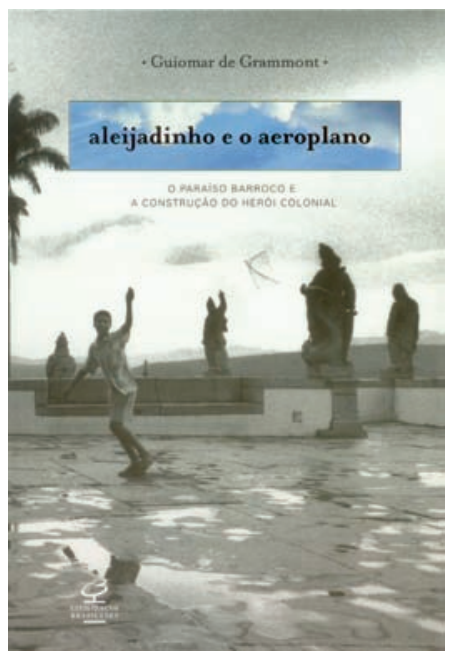

GRAMMONT, Guiomar de. Aleijadinbo e o aeroplano: o paraíso barroco e a construção do herói colonial. Rio de Janeiro: Civilização Brasileira, 2008. 322p.

supostamente, o unissem à Europa, a figura do Aleijadinho, assim composta, é também resposta, para a crítica modernista ideologicamente comprometida, do colonizado contra o colonizador. Nasce desse modo outra representação, cujos desdobramentos tornaram-se evidentes em leituras posteriores, durante o século $\mathrm{XX}$, como a do mito poético inventado por Lezama Lima, ou seja, o da arte da cultura criolla como arte de resistência ou "arte da contraconquista".

Se, porém, a Bretas e às ações do IHGB coube a composição do personagem Aleijadinho em chave romântica, aos pesquisadores do Sphan, contudo, sob a direção de Rodrigo Melo de Franco Andrade, coube a missão, segundo Guiomar, de provar cabalmente a existência do artista verdadeiro, assim como da recolha de indícios que pudessem comprovar a autoria das obras a ele atribuídas. Aparentemente comprometidos não com a verificação da farsa montada por Bretas, mas com a sua naturalização, 
os pesquisadores do Sphan contribuíram para falseá-la, aceitando os dispositivos textuais presentes em seu discurso como testemunhos factuais da história do personagem. Ignoraram, assim, como o demonstra argutamente Guiomar, as condições históricas específicas da instituição colonial brasileira, no século XVIII, para as quais seriam impensadas ações autorais autônomas, e anômalas, causando rupturas no exercício das artes.

Pensadas como imitação e emulação de partes de doutrinas autorizadas no tempo em que eram feitas, as artes que hoje recebem a classificação de "barrocas" praticavam-se antes como hábitos intelectivos ativos assim como o que se expõe na doutrina tomista e neoaristotélica. Não se produziam essas artes de forma autoral nem muito menos eram elas desatreladas de doutrinas que as investiam nos gêneros já sabidos pela sua audiência, ao contrário da audiência atual, e desde o XIX, que as desconhece ou ignora. Para a teoria ou estética kantiana (e neokantiana), contudo, detentora da atenção da audiência atual, a arte teria como única origem e regra, a natureza, como sujeito, dotada no artista, não em todo, mas apenas no indivíduo genial.

O Aleijadinho foi, assim, postulado, a par dessa teoria, e de outras, oriundas do romantismo, como uma unidade psicossociológica, tendo deixado rastros de sua existência em documentos que atestariam o seu nascimento, vida ou morte, ou nas marcas de sua ação sobre a matéria da obra supérstite, que, mais do que tudo, evidenciaria a sua personalidade genial. Sequente à análise das características formais dessa personalidade e sua obra, deuse outra representação do artista, como façanha de Germain Bazin, sempre cultuado pelos pesquisadores do Sphan.
Bazin sugeriu em seus estudos uma relação entre as deformidades físicas trazidas pela doença que acometeu o artista e as distorções em suas figuras escultóricas, relação a que nomeou de "projeções morfopsicológicas". Assim, sugere, a dor que o deforma, deforma as suas obras, onde se deixam ver, expressivas, as marcas de "ancião atingido por uma doença cruel”, produzindo da sua mão perfeita, mesmo a tendo, atrofiada, obra magnífica. Infelizmente, essas oposições, presentes nos textos de Bretas e de José Joaquim da Silva, foram naturalizadas por Bazin e outros, à caça de precisão histórica que confirmassem o Aleijadinho "real" no centro da produção de algumas obras, por esse nome, autorizadas.

Como bem lembra Guiomar, ao discurso "morfopsicológico" agregou-se o médico, tendo aliás sido produzida uma lista de diagnósticos em convenção de doutores mineiros, fantástica, senão risível, dos possíveis males que abateram o artista, acobertados sob o "estigma do mal de Hansen". Risível é tal lista, sobretudo, porque outro Hansen, o crítico João Adolfo, libera o personagem de tal fardo, auxiliando a autora a inventar as tópicas onde se inscreveriam como prosopografia os caracteres e as paixões do "Aleijadinho", não o suposto, mas o personagem.

As deformações ou deformidades nas obras escultóricas daquele, por exemplo, seriam devidas a efeitos, desejados para o espectador, potencialmente ativos a partir de adições ópticas na cenografia em que se figuram os objetos assim como nesses próprios, e percebidos pelo olho numa distância calculada. Pois, propõe João Adolfo Hansen, no prefácio do livro, a arte, à época, não é "barroca" em estilo, nem se personaliza em torno de 
um artista genial, o que seria impensado e anacrônico, mas constrói-se como Theatrum Sacrum, e assim foi investida pelo aparato teológico e político colonial.

Não interessada em analisar profundamente os dispositivos que operam a obra em seu tempo, mas não deixando de referi-los à medida que avança na reconstrução histórica da construção do personagem "Aleijadinho", Guiomar enlaça os participantes dessa ação num discurso que imita, a distância, a novela. Reconstitui, desse modo, a contenda, entre os defensores do mito "Aleijadinho" e os seus detratores, revelando ao leitor detalhes do que, muitas vezes, se assemelha também à crônica policial, com exumação de cadáveres, incêndios inoportunos, ou oportunos, dependendo do ponto de vista, e documentos pertencentes a ordens religiosas que desaparecem misteriosamente, sem deixar vestígios, se é que alguma vez existiram. Há, de fato, tantas histórias relativas à construção desse personagem, com interesses tão diversos a cada vez, que não causaria estranhamento a sua utilização para a composição de uma ficção que se explicitasse como tal.

Coube a Guiomar, no entanto, demonstrar os dispositivos que estão aquém desses discursos, sem pender para quaisquer dos lados referidos, uma vez que a negação veemente da crença na existência do indivíduo por detrás do mito só ajudaria a reforçá-la.

Por isso, também recolhe e comenta as notícias dos viajantes como Saint-Hilaire, Burton, Eschwege, que passaram por Minas no século XIX e início do XX, acrescentando-lhes, em visada oposta, a crítica dos modernistas, sobretudo, a de Mário de Andrade. Ao insistir, na senda de Cendrars, possivelmente, em referir a arte brasileira às suas próprias origens, Mário, a exemplo de outros modernistas, intentou em seu discurso a "redescoberta" da arte brasileira, fazendo de categorias como genialidade e genuinidade chaves para o louvor da cultura mestiça ou miscigenada. Como propõe Guiomar, para Mário, “o Aleijadinho é o herói, que, como alquimista, promove a transubstanciação dos elementos [...] transforma a cultura de importações irregulares em algo próprio e inédito".

À medida que o erige como herói, Mário faz proliferar, à volta de sua entidade subjetiva, desvios de natureza estilística e étnica, como propôs Elisa Kossovitch. Assim, o estilo do Aleijadinho não é o "barroco", pois sempre escapa ou desliza para "bizantinismos", "goticismos", "renascentismos", "expressionismos" etc., assim como não se classificam as suas ações na colônia como típicas do "mulato", pois, extraordinárias à lida do mestiço colonial, miram o sujeito "desraçado". Incutida de uma "verdade interior", a arte de Aleijadinho é desviante de categorias que poderiam introjetá-la na, assim chamada, Renascença italiana.

Como desviante, o estilo do Aleijadinho atenua a expressão do barroco, fazendo-o "dócil" e "pequenininho", "feito para acarinhar", segundo Mário, o que implica a contenção como afeição pela plasticidade. Desviando-se desta última, que é determinação da fase sã, opera Aleijadinho, na fase da doença, antiplástica, em oposição àquela, a deformação, na qual a gentileza é substituída pela fúria, segundo Kossovitch.

Desviante em relação ao expressionismo alemão, também, a arte de Aleijadinho da fase de Congonhas lhe é, contudo, análoga, pois, afastando-se do pejo de "primitivista", revelou-se uma 
arte feita com franca "intenção expressiva". Como "deformador sistemático" ou "raro realista", o Aleijadinho de Mário de Andrade, afasta-se, porém, da vanguarda europeia, atenuando-lhe o páthos, a simpatia pelo nacional. Como desviante, em sentido contrário, à noção de abstração, necessária às teses sobre o expressionismo alemão, conforme Worringer, a "intenção expressiva" na arte de Aleijadinho refere ainda a Einfüblung, numa espécie de ocaso do romantismo.

Na eleição de autores modernos que problematizaram o ensaio de Mário de Andrade e sua relação com o modernismo brasileiro, Guiomar se utiliza da voz de outros para revelar a artificialidade do caráter mítico do Aleijadinho, ou do artista genial que ergueu as suas obras, feitas de um sublime "pequenininho", contra o céu azul cobalto das fotos que hoje as ilustram, em Vila Rica e arredores. Poderia muito bem, nesse céu de fim de tardezinha, ter voado, como outra tópica circulante, o aeroplano leonardivinciano, que o conde Affonso Celso projetou em seu discurso, para o "Aleijadinho", de 1911.

Luiz Armando Bagolin é professor do Instituto de Estudos Brasileiros (IEB) da USP. @-lbagolin@usp.br 